\title{
Peluang Efisiensi Penggunaan Energi pada Sektor Perhotelan di Kota Jambi
}

\author{
${ }^{1}$ Myson \\ ${ }^{1}$ Prodi Teknik Listrik Unbari \\ myson_ade1@yahoo.com
}

\begin{abstract}
Abstrak
Dalam RPJMN 2015-2019 pemerintah menetapkan target wisatawan mancanegara mencapai 20 juta orang pada tahun 2019. Sektor perhotelan berkontribusi terhadap penggunaan energi nasional sebesar 3\%. Sektor perhotelan berkembang dengan laju pertumbuhan 12,5\% dari 2007 sampai 2011, sebagai respon terhadap peningkatan jumlah wisatawan antara 9-13\% termasuk di kota Jambi pada kurun waktu tersebut. Untuk mengevaluasi penggunaan energi listrik pada hotel perlu melakukan analisa biaya energi per kamar hotel yang terjual untuk memberikan gambaran rata-rata biaya energi. Dari perhitungan didapatkan bahwa intensitas konsunsi energi pada salah satu kamar hotel di kota jambi adalah sebesar 5,93 $\mathrm{kWh} / \mathrm{m}^{2}$.
\end{abstract}

Key words : Energi, konservasi energi, hotel

\begin{abstract}
In the RPJMN 2015-2019 the government sets a target of 20 million foreign tourists by 2019. The hotel sector contributes to national energy use of 3\%. The hospitality sector is growing at a 12.5\% growth rate from 2007 to 2011, in response to an increase in the number of tourists between 9-13\% including in Jambi at that time. To evaluate the use of electric energy at the hotel it is necessary to conduct an analysis of energy costs per hotel room sold to give an average picture of energy costs. From the calculation, it is found that the intensity of energy consumption in one of the hotel rooms in jambi city is $5.93 \mathrm{kWh} / \mathrm{m} 2$.
\end{abstract}

Key words: Energy, energy conservation, hotel

\section{PENDAHULUAN}

Pada tahun 2015 pemerintah Indonesia mentargetkan kunjungan wisata mencapai 10 juta orang lebih. Untuk melaksanakan ini diperlukan dukungan dari beberapa pihak yang salah satunya adalah perhotelan. Berdasarkan riset yang dilakukan oleh USAID yang bekerjasama dengan ICED dan kementerian ESDM pada tahun 2011 menyimpulkan bahwa "Bangunan, termasuk didalamnya bangunan hotel menggunakan 50\% energi secara umum, atau 70\% listrik dari total konsumsi di Indonesia dan menjadikan sektor ini sebagai pengguna energi terbesar yang melebihi sektor industri dan transportasi. Besarnya konsumsi energi pada bangunan ini berkontribusi terhadap tingginya biaya operasional bangunan tersebut sesesar 25\%-30\%. Selain itu juga berkontribusi pada emisi gas rumah kaca yang cukup besar dan hal ini berdampak pada pemanasan global.

Permasalahan yang ditinja dalam penelitian ini adalah masih tingginya penggunaan energi pada sub sektor perhotelan di kota Jambi dan masih kurangnya upaya yang dilakukan untuk melaksanakan efisiensi energi pada sektor perhotelan di kota Jambi.

Karena luasnya permasalahan yang ada pada bidang konservasi energi maka penelitian ini hanya melakukan audit awal pada penggunaan energi listrik hotel di 
kota jambi. Pada penelitian ini peneliti membatasi persoalan pada peluang efisiensi penggunaan energi listrik salah satu hotel di Kota Jambi.

Penelitian ini bertujuan untuk: 1) Mengukur seberapa besar penggunaan energi listrik pada salah satu hotel dikota Jambi; 2) Dengan dilaksanakannya efisiensi energi pada sub sektor perhotelan ini dapat menekan jumlah pemakaian energi dari sub sektor ini; 3) Dengan dilaksanakannya efisiensi energi pada sub sektor perhotelan ini akan dapat menekan biaya operasional hotel.

Sedangkan manfaat dari penelitian ini adalah: 1) Dengan berkurangnya penggunaan energi pada hotel, maka biaya operasional hotel akan berkurang dan akan berdampak pada biaya sewa kamar hotel; 2) Dengan menurunnya biaya sewa kamar hotel, maka akan dapat meningkatkan jumlah hunian kamar hotel; 3) Dengan meningkatnya jumlah hunian kamar hotel akan berdampak pada keuntungan industri perhotelan itu sendiri; 4) Dengan demikian salah satu aspek pendukung kunjungan wisata ke daerah di Indonesia akan meningkat.

Urgensi Penelitian: 1) Dengan makin berkurangnya jumlah cadangan energi untuk mendukung kehidupan ini, maka perlu dilakukan penghematan dalam menggunakan energi tersebut; 2) Dilain pihak dengan makin berkurangnya cadangan energi ini akan meningkatkan harga jual energi, sehingga masyarakat miskin akan menjadi sangat sulit dalam mengakses kebutuhan energi mereka.

Pariwisata dikategorikan dalam kelompok industri terbesar dunia (the world's largest industry), sebagaimana dinyatakan pula oleh Naisbitt. Sekitar 8\% dari ekspor barang dan jasa, berasal dari sektor pariwisata. Pariwisata telah menjadi penyumbang terbesar dalam perdagangan internasional dari sektor jasa, kurang lebih 37\%. Di Asia Tenggara pariwisata menyumbangkan 10-12\% dari GDP, dan 7-8\% dari total employment.

Pemerintah telah menetapkan pariwisata sebagai sektor prioritas yang mampu mendorong ekonomi. Dalam RPJMN 2015-2019 pemerintah menetapkan target kunjungan wisatawan mancanegara hingga 20 juta orang pada tahun 2019. Untuk mendorong surplus jasa perjalanan, selain menjaring sebanyak mungkin wisatawan mancanegara untuk berkunjung ke Indonesia, perlu pula mendorong masyarakat Indonesia untuk lebih memilih berwisata di dalam negeri.

Akomodasi perhotelan tidak dapat dipisahkan dengan pariwisata. Tanpa kegiatan kepariwisataan dapat dikatakan akomodasi perhotelan akan lumpuh. Sebaliknya pariwisata tanpa hotel merupakan suatu hal yang tidak mungkin, apalagi kalau kita berbicara pariwisata sebagai suatu industri.

Tour, dimana perjalanan dilakukan lebih dari 24 jam. Dengan demikian memerlukan tempat tinggal sementara selama dalam perjalanan agar dapat beristirahat, mandi dan makan. Industri pariwisata dewasa ini sudah memasuki era "mass-tourism", dimana orang tidak lagi melakukan perjalanan sendiri-sendiri, tetapi berombongan (group). Hal ini dimungkinkan karena berkembangnya penerbangan borongan (charter flight) dan tersedianya fasilitas akomodasi dalam jumlah kamar yang relatif banyak. Dahulu hal ini telah dilakukan oleh Thomas Cook pada tahun 1841, dengan menyewa kereta api untuk membawa wisatawan sebanyak lebih kurang 500 orang dalam excursion yang dilakukan antara kota Leicester dan kota Loughborough.

Bila dengan kondisi semacam ini tidak disiapkan sarana perhotelan dengan segala fasilitasnya, dapat dibayangkan bahwa akan terjadi stagnasi dalam penerimaan kunjungan wisatawan yang hari demi hari terus meningkat. Saat ini sedang berkembang jenis pariwisata yang pasarannya adalah orang yang melakukan perjalanan untuk tujuan komprensi, seminar, simposium, loka karya, 
musyawarah nasional dan kegiatan lain semacam itu yang tentunya membutuhkan fasilitas dan sarana yang lengkap dan banyak.

Dalam bisnis perhotelan energi sangatlah penting, terutama energi listrik. Hal ini dapat dilihat bahwa peralatan seperti lampu-lampu, lift, lemari es, laundry, pemanas, pompa-pompa, sampai pada sistem pengkondisian udara adalah beberapa alat yang dominan dipakai dalam dunia perhotelan. Usaha-usaha penghematan energi listrik telah dilaksanakan oleh pihak hotel seperti melakukan penjadwalan operasional peralatan, penggantian lampu-lampu dengan lampu hemat energi dan pemasangan kapasitor bank, akan tetapi biaya operasional energi listrik tetap melebihi standar yang telah ditentukan.

Untuk menanggulangi masalah tersebut dilakukan efisiensi energi. Salah satu metode yang dipakai untuk mengefisienkan pemakaian energi listrik adalah konservasi energi. Pada proses ini meliputi adanya audit energi yaitu suatu metode untuk mengitung tingkat konsumsi energi suatu gedung atau bangunan, yang mana hasilnya nanti akan dibandingkan dengan standar yang ada untuk kemudian dicari solusi penghematan konsumsi.

Untuk audit energi dan peluang penghematan energi diutamakan pada sistem pengkondisian udara karena penggunaan energi listriknya dapat mencapai $60 \%$ melebihi standar yang disampaikan oleh Tim Hemat Energi (THE) yaitu 48,50\%. Untuk itu diperlukan adanya perhitungan IKE (Intensitas Konsumsi Energi). Dimana, IKE adalah pembagian antara konsumsi energi dengan satuan luas bangunan gedung.

\section{Peluang Efisiensi energi}

Sektor perhotelan termasuk dalam sektor komersial yang berkontribusi terhadap penggunaan energi nasional sebesar 3\% dengan laju pertumbuhan sebesar $8,6 \%$ per tahun. Sektor perhotelan sendiri berkembang dengan sangat pesat di Indonesia, dengan laju pertumbuhan 12,5\% dari 2007 sampai 2011, sebagai respon terhadap peningkatan jumlah wisatawan antara 9-13\% pada kurun waktu tersebut.

Penggunaan energi yang efisien di bangunan hotel menunjukan bahwa energi digunakan seoptimal mungkin guna memenuhi kebutuhan tamu tanpa adanya energi yang terbuang atau berlebihan. Dalam prakteknya, penghematan energi di bangunan hotel tetap mengedepankan prinsip

4K, yaitu:

1. Kenyamanan

2. Keselamatan

3. Keindahan/estetika

4. Kelancaran staf bekerja

Kecenderungan Pola Penggunaan Energi di Bangunan Hotel Per Wilayah di Indonesia pada Tahun 2013

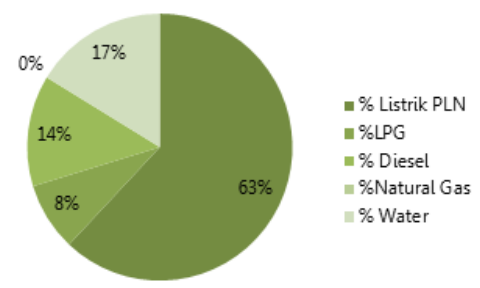

Gambar 1. Pola penggunaan energi pada hotel-hotel di Bali 


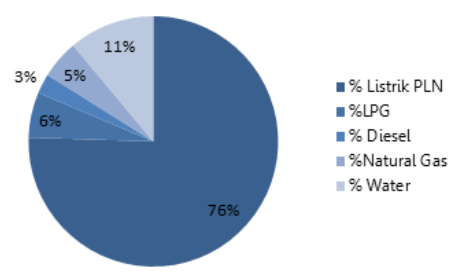

Gambar 2. Pola penggunaan energi pada hotel-hotel di Jakarta

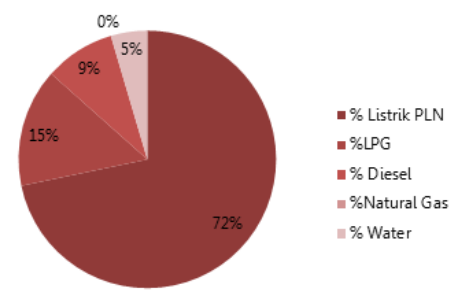

Gambar 3. Pola penggunaan energi pada hotel-hotel di Yogyakarta

\section{Perhitungan Biaya Energi di Bangunan Hotel}

Komponen biaya energi di hotel biasanya dinyatakan dalam satuan biaya per kamar yang terjual, atau jumlah total kamar hotel. Idealnya, perhitungan biaya energi tersebut dilakukan setiap hari dan dilaporkan kepada manajemen serta divisi lainnya dalam mendukung program penghematan energi. Selain itu, perhitungan dan pelaporan secara berkala merupakan bagian dari proses review dan evaluasi dalam program manajemen energi yang baik, sehingga dapat dianalisa dan diketahui trend penggunaan energi di hotel. Hal ini dapat dipergunakan untuk membantu perencanaan penurunan konsumsi energi di kamar hotel secara bertahap, atau sebagai bagian dari program kepedulian lingkungan hidup secara keseluruhan. Dalam program "Hotel Energy Benchmarking and Strategic Energy Management”, USAID-ICED juga melakukan analisa biaya energi per kamar hotel yang terjual untuk memberikan gambaran rata-rata biaya energi tersebut, terutama untuk hotel Bintang 4 dan 5.

Biaya Energi $=$ Total biaya listrik kWh)/jumlah kamar yang terjual Atau

Biaya Energi =(total biaya energi (listrik, diesel, gas dalam kWh)/(jumlah kamar terjual)(dalam unit harian/bulanan/tahunan)

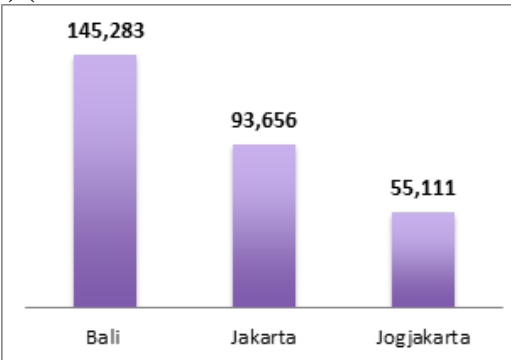

Gambar 4. Harga rata-rata biaya energi per kamar

Rata-rata biaya energi dan air per kamar per hari di tiap kota di Indonesia memiliki perbedaan yang cukup signifikan. Bali dengan biaya tertinggi mencapai Rp. 145,283 terjadi karena mayoritas wisatawan asing yang datang terbiasa dengan temperatur udara rendah. Jakarta di posisi kedua dengan biaya Rp. 93,656 per kamar per hari, sedangkan Yogyakarta dengan biaya terendah sebesar Rp. 55,111 yang meliputi hotel Bintang 3 di dalamnya. 
Konsumsi energi pada bangunan hotel dapat dinyatakan dalam:

1. IKE (Intensitas Konsumsi Energi) atau EUI (Energy Use Intensity)

Angka yang menunjukkan jumlah energi yang dikonsumsi (dalam $\mathrm{kWh}$ ) untuk setiap $\mathrm{m}^{2}$ luas bangunan yang terkondisikan dengan system pendingin udara per tahun.

IKE=Konsumsi energi $(\mathrm{kWh})$ dalam 1 tahun / luasbangunan yang terkondisikan $\left(\mathrm{m}^{2}\right)$

Rata-rata IKE untuk 30 hotel dalam pilot program ICED adalah 393 $\mathrm{kWh} / \mathrm{m}^{2} /$ tahun

(konsumsi energi (kWh) dalam 1 tahun)(luas bangunan yang terkondisikan $(\mathrm{m} 2)$

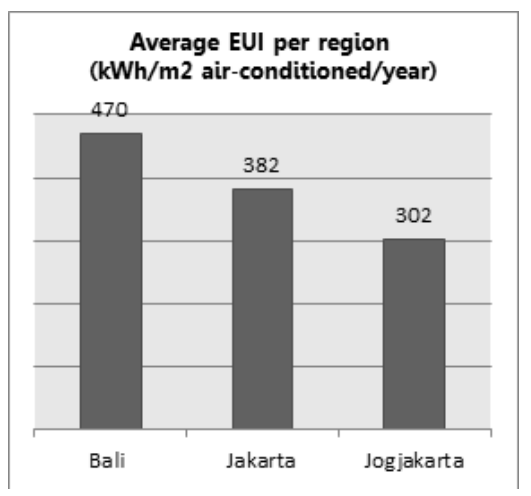

Gambar 5. Rata-rata intensitas energi pada masing-masing kota

2. REI (Room Energy Intensity)

Angka yang menunjukkan jumlah energi yang dikonsumsi (dalam $\mathrm{kWh}$ ) untuk setiap kamar yang terjual per tahun.

$\mathrm{IKE}=($ konsumsi energi $(\mathrm{kWh})$ dalam 1 tahun /(jumlah kamar $\mathrm{x}$ okupansi)

Rata-rata REI untuk 30 hotel dalam pilot program ICED adalah 137 $\mathrm{kWh} / \mathrm{kamar} / \mathrm{tahun}$

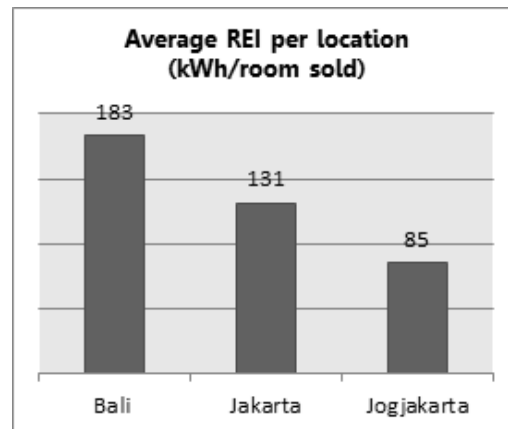

Gambar 6. Rerata energi yang dikonsumsi untuk tiap kamar yang terjual per tahun

3. Benchmark Score, menggunakan benchmarking tool

Suatu nilai, dalam rentang 1-100, yang menunjukkan tingkat efisiensi konsumsi energi sebuah hotel, relatif terhadap hotel lain yang sejenis di Indonesia. 1 berarti kurang efisien, 100 berarti paling efisien dibandingkan hotel lainnya.

Rata-rata Benchmark Score untuk Program Percontohan Hemat Energi Hotel oleh ICED: 48, artinya bahwa tingkat efisiensi konsumsi energi ratarata ke-30 hotel masih berada di bawah rata-rata,dibandingkan hotel serupa di Indonesia. 


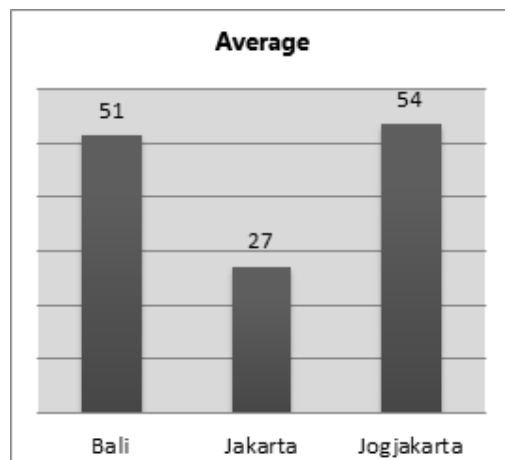

Gambar 7. Rata-rata benchmark score hotel pada beberpa daerah

Tabel 1. Standar Intensitas Konsumsi Energi Indonesia

\begin{tabular}{lc|lr}
\hline \multicolumn{2}{l|}{ Ruangan dengan AC (kWh/m²/bulan) } & \multicolumn{2}{l}{ Ruangan tanpa AC (kWh/m²/bulan) } \\
\hline Sangat effisien & $4,17-7,9$ & Cukup Effisien & $0,84-1,67$ \\
Effisien & $7,92-12,08$ & Cenderung tidak Effisien & $1,67-2,50$ \\
Cukup Effisien & $12,08-14,58$ & Tidak Effisien & $2,50-3,34$ \\
Cenderung Tidak Effisien & $14,58-19,17$ & Sangat tidak Effisien & $3,34-4,17$ \\
Tidak Effisien & $19,17-23,75$ & & \\
Sangat tidak Effisien & $23,75-37,50$ & & \\
\hline
\end{tabular}

\section{METODE PENELITIAN}

Metode yang dipakai pada penelitian ini adalah deskriptif kualitatif dengan mengambil data-data yang dibutuhkan pada satu hotel yang telah di setujui untuk dilakukan audit awal atas penggunaan energi pada hotel tersebut. Data di hitung dan dianalisa dibandingkan dengan nilai rata-rata hotel yang ditetapkan oleh pemerintah.

\section{Data}

a. Hotel tempat pengambilan data memiliki luas kamar seperti pada tabel dibawah ini

Tabel 2. Jumlah Luas Kamar

\begin{tabular}{lcccc}
\hline Tipe Kamar & $\begin{array}{c}\text { Jumlah } \\
\text { kamar }\end{array}$ & $\begin{array}{c}\text { Luas kamar } \\
\left(\mathrm{m}^{2}\right)\end{array}$ & Jumlah $\left(\mathrm{m}^{2}\right)$ & Ket \\
\hline Superior & 30 & 40 & 1200 \\
Deluxe & 50 & 36 & 1800 \\
Eksekutive & 5 & 50 & 250 \\
Suite & 1 & 70 & 70 \\
Jumlah & & & 3320 \\
\hline
\end{tabular}

b. Penggunaan lampu penerangan

Data penggunaan lampu penerangan di sajikan dalam bentuk tabel dibawah ini dengan asumsi penggunaan lampu selama 1 hingga 8 jam per hari dan tingkat occupancy sebesar $65 \%$.

Tabel 3. Pemakaian Daya Listrik per hari untuk lampu

\begin{tabular}{|c|c|c|c|c|c|c|c|}
\hline \multirow{2}{*}{$\begin{array}{l}\text { Tipe } \\
\text { Kamar }\end{array}$} & \multirow{2}{*}{$\begin{array}{c}\text { Jumla } \\
\text { h } \\
\text { kama }\end{array}$} & \multicolumn{3}{|c|}{ Lampu (9W) } & \multirow{2}{*}{$\begin{array}{c}\text { Wakt } \\
\text { u } \\
(\mathrm{Jam})\end{array}$} & \multicolumn{2}{|c|}{$\begin{array}{c}\text { Total Pemakaian Daya Per Hari } \\
(\mathrm{kWh})\end{array}$} \\
\hline & & $\mathrm{TL}$ & $\mathrm{HE}$ & $\begin{array}{c}\text { Le } \\
\text { d }\end{array}$ & & $\begin{array}{c}\text { Tanpa } \\
\text { occupancy }\end{array}$ & $\begin{array}{l}\text { Dengan } \\
\text { Occupancy }\end{array}$ \\
\hline
\end{tabular}




\begin{tabular}{lccccc}
\hline Superior & 30 & 21 & $1-8$ & 1,89 & 1,092 \\
& & 0 & & & \\
Deluxe & 50 & 10 & $1-8$ & 0,9 & 0,52 \\
& & 0 & & & \\
Executive & 5 & 45 & $1-8$ & 0,405 & 0,234 \\
Suite & 1 & 30 & $1-8$ & 0,27 & 0,156 \\
Jumlah & & 38 & & 3,465 & 2,002 \\
& & 5 & & & \\
\hline
\end{tabular}

Maka di dapatkan hasil perhitungan pemakaian daya listrik per hari untuk penerangan adalah sebesar 2,002 $\mathrm{kWh}$, sehingga untuk satu bulan penggunaan daya listrik untuk penerangan adalah $60,06 \mathrm{kWh}$.

c. Penggunaan Televisi 32" LED

Dengan perkiraan penggunaan televisi sekitar 7 jam dengan asumsi occupacy $65 \%$ maka diperoleh hasil seperti pada tabel dibawah ini

Tabel 4. Pemakaian daya listrik per hari untuk Televisi

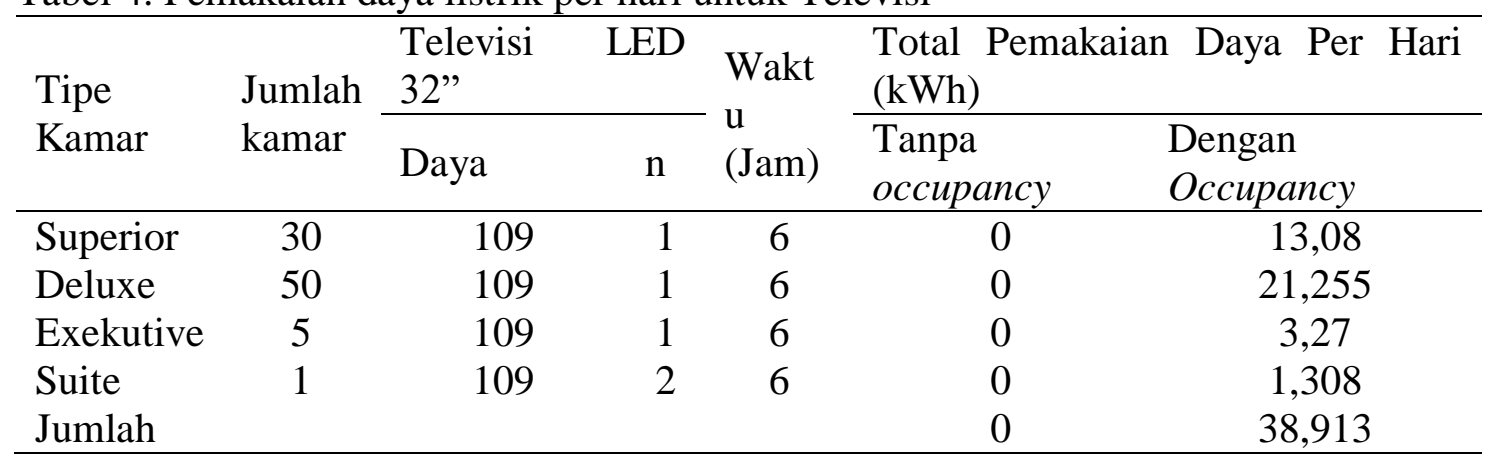

Dengan demikian didapatkan hasil perhitungan bahwa pemakaian energi listrik untuk keperluan televisi selama 7 jam dalam sehari adalah sebesar $38,913 \mathrm{kWh}$ sehingga untuk satu bulan didapatkan konsumsi sebesar 1167,36 $\mathrm{kWh}$.

d. Penggunaan Air Conditioner

Perkiraan penggunaan air conditioner selama 10 jam dengan kekuatan 1 pk pada tingkat occupancy $65 \%$, maka didapatkan hasil perhitungan konsumsi daya listrik sebayak seperti tabel di bawah ini.

Tabel 5. Pemakaian daya listrik per hari untuk Air Conditioner

\begin{tabular}{|c|c|c|c|c|c|c|}
\hline \multirow{2}{*}{$\begin{array}{l}\text { Tipe } \\
\text { Kamar }\end{array}$} & \multirow{2}{*}{$\begin{array}{l}\text { Jumlah } \\
\text { kamar }\end{array}$} & \multicolumn{2}{|c|}{$\begin{array}{l}\text { Air Conditioner } \\
1 \mathrm{pk}\end{array}$} & \multirow{2}{*}{$\begin{array}{l}\text { Wakt } \\
\text { u } \\
\text { (Jam) }\end{array}$} & \multicolumn{2}{|c|}{$\begin{array}{l}\text { Total Pemakaian Daya Per Hari } \\
(\mathrm{kWh})\end{array}$} \\
\hline & & Daya & $\mathrm{n}$ & & $\begin{array}{l}\text { Tanpa } \\
\text { occupancy }\end{array}$ & $\begin{array}{l}\text { Dengan } \\
\text { Occupancy }\end{array}$ \\
\hline Superior & 30 & 1000 & 1 & 10 & 0 & 195 \\
\hline Deluxe & 50 & 1000 & 1 & 10 & 0 & 325 \\
\hline Exekutive & 5 & 1000 & 1 & 10 & 0 & 32,5 \\
\hline Suite & 1 & 1000 & 2 & 10 & 0 & 13 \\
\hline Jumlah & & & & & 0 & 565,5 \\
\hline
\end{tabular}

Dengan hasil perhitungan diatas didapatkan bahwa kebutuhan guna menghidupan air conditioner (AC) dengan penggunaan selama 7 jam dalam satu hari dengan tingkat occupancy sebesar $65 \%$ adalah sebesar $565 \mathrm{kWh}$. Dengan demikian maka kebutuhan daya listrik untuk satu bulan guna keperluan pengkondisian udara adalah $16.965 \mathrm{kWh}$. 


\section{e. Water heater pot}

Water heater pot diperlukan oleh setiap penyewa kamar guna keperluan memanaskan air untuk minum teh atau kopi. Dengan tingkat occupancy 65\% maka penggunaan daya listrik untuk keperluan teko water heater seperti pada tabel dibawah ini.

Tabel 6. Pemakaian daya listrik per hari untuk Water heater pot

\begin{tabular}{|c|c|c|c|c|c|c|}
\hline \multirow{2}{*}{$\begin{array}{l}\text { Tipe } \\
\text { Kamar }\end{array}$} & \multirow{2}{*}{$\begin{array}{l}\text { Jumlah } \\
\text { kamar }\end{array}$} & \multicolumn{2}{|c|}{$\begin{array}{l}\text { Water heater } \\
\text { pot }\end{array}$} & \multirow{2}{*}{$\begin{array}{c}\text { Wakt } \\
\mathrm{u} \\
(\mathrm{Jam})\end{array}$} & \multicolumn{2}{|c|}{$\begin{array}{l}\text { Total Pemakaian Daya Per Hari } \\
\qquad(\mathrm{kWh})\end{array}$} \\
\hline & & Daya & $\mathrm{n}$ & & $\begin{array}{c}\text { Tanpa } \\
\text { occupancy }\end{array}$ & $\begin{array}{c}\text { Dengan } \\
\text { Occupancy }\end{array}$ \\
\hline Superior & 30 & 300 & 1 & 1 & 0 & 5,85 \\
\hline Deluxe & 50 & 300 & 1 & 1 & 0 & 9,75 \\
\hline Exekutive & 5 & 300 & 1 & 1 & 0 & 0,975 \\
\hline Suite & 1 & 300 & 2 & 1 & 0 & 0,39 \\
\hline Jumlah & & & & & 0 & 16,965 \\
\hline
\end{tabular}

Dengan demikian didapatkan bahwa penggunaan listrik untuk keperluan memanaskan air minum adalah sebesar $16,965 \mathrm{kWh}$, maka penggunaan daya listrik untuk teko pemanas air dalam satu bulan adalah 508,95 kWh.

f. Jumlah kebutuhan penggunaan listrik untuk peralatas yang ada di kamar hotel selama satu bulan dengan tingkat occupancy $65 \%$ adalah sebagai berikut :

Tabel 7. Total kebutuhan daya listrik kamar hotel perhari

\begin{tabular}{clc}
\hline No & Jenis Peralatan & Kebutuhan daya $(\mathrm{kWh})$ \\
\hline 1 & Lampu penerangan & 60,06 \\
2 & Televisi & 1167,36 \\
3 & Air Conditioner (AC) & $16.965,00$ \\
4 & Water heater pot & 508,95 \\
5 & Lain-lain & 1000,00 \\
& Jumlah & 19701,37 \\
\hline
\end{tabular}

Perhitungan IKE kamar hotel

Dengan rumus yang telah di sampaikan pada teori maka intensitas konsumsi energi dalam satu bulan adalah sebagai berikut :

IKE $=$ Total konsumsi listrik/ luas area kamar hotel

$=19701,37 / 3320$

$=5,93 \mathrm{kWh} / \mathrm{m}^{2}$

Dari perhitungan diatas, maka didapatkan bahwa intensitas konsunsi energi pada kamar hotel tersebut adalah sebesar $5,93 \mathrm{kWh} / \mathrm{m}^{2}$

\section{SIMPULAN} berikut:

Dari hasil perhitungan dan analisa bahwa dapat disimpulkan sebagai

1. Intensitas konsumsi energi pada salah satu hotel di jambi masih memenuhi kriteria sangat effisien, karena didapatkan angka kebutuhan listrik untuk satu meter persegi adalah $5,93 \mathrm{kWh} / \mathrm{m}^{2}$ dalam satu bulan.

2. Intensitas konsumsi energi listrik yang rendah ini dimungkinkan karena banyak menggunakan peralatan yang sudah hemat energi, seperti lampu HE, televisi LED dan air condition yang rendah konsumsi energi listriknya.

3. Dengan tingkat intensitas konsumsi energi yang rendah ini, peluang kamar hotel untuk di jual dengan harga yang lebih rendah masih memungkinkan. 


\section{Saran}

Dengan didapatkan hasil audit awal pada salah satu hotel yang ada di jambi maka beberapa saran perlu penulis sampaikan:

1. Pihak hotel sebaiknya sering malakukan audit atas pemakaian energi terutama energy listrik.

2. Hendaknya pihak hotel tidak alergi dan lebih terbuka terhadap audit energi, karena hasil audit sangat bermanfaat untuk pihak pengelola hotel dalam memasarkan kamar hotelnya sehingga tingkat occupancy dapat lebih tinggi lagi.

3. Pemerintah melalui dinas ESDM provinsi Jambi dapat mensosialisasikan pentingnya audit energi, baik untuk pemerintah maupun swasta.

4. Audit awal ini sebaiknya dilanjutkan dengan audit energy yang lebih dalam, sehingga akan didapatkan hasil yang lebih kongkrit dan menyeluruh.

\section{DAFTAR PUSTAKA}

Adrian Bejan, 1988, 'Advanced Engineering Thermodynamics', Jhon Wiley\&son.Inc

Hasan Basri, Dr.Ir, 2007, ' Teknik Kogenerasi (bahan kuliah),PPs Unsri, Palembang.

Notodisuryo, Endro Utomo, 2-3 September 1991, 'Kebijakan Konservasi energi nasional (Makalah Seminar Energi)', Jakarta; Direktorat Pengembangan Energi Baru Departemen Pertambangan dan Energi Indonesia.

Rianto, Agus, et al. Audit Energi Dan Analisis Peluang Penghematan Konsumsi Energi Pada Sistem Pengkondisian Udara Di Hotel Santika Premiere Semarang. 2007. PhD Thesis. Universitas Negeri Semarang.

Roger Kinsky M.Eng,Sc.,B.E.,B.Sc, 'Applied Heat',An Introduction to thermodynamics, Second edition.

USAID-ICED,'Panduan Praktis Penghematan Energi di Hotel", Jakarta, Indonesia Clean EnergyDevelopment, Februari 2015

www.energyefficiencyasia.org (OUNEP, Pedoman Efisiensi Energi untuk Industri di Asia 